\title{
Optimasi Metode dan Uji Stabilitas pada Penetapan Kadar Filantin dalam Ekstrak Phyllanthus niruri Menggunakan KLT-Densitometri
}

Rachma Nurhayati, Riesta Primaharinastiti, Mochammad Yuwono*

Departemen Kimia Farmasi, Fakultas Farmasi, Universitas Airlangga, Surabaya, Indonesia

*Coresponding author: yuwono05@yahoo.com

Submitted: 11 Februari 2020

Accepted: 10 April 2020

Published: 30 November 2020

\begin{abstract}
Background: Phyllanthin is the major lignan compound in Phyllanthus niruri with hepatoprotective activity. For the standardization of P. niruri extracts, a simple and selective TLC-densitometric method has been developed, and phyllanthin was used as a phytochemical marker in this study. Objective: To obtain the optimal condition of the separation and to evaluate the stability of phyllanthin as a pre-validation stage by using TLC-densitometry. Methods: Optimal conditions were studied in the variation of the mobile phase composition, the analytical wavelength, the saturation time of TLC chamber, the elution distance and the volume of the spot. The stability test was done by analyzing the standard and extract solutions at 0, 4, 8, and 24 hours. Results: The composition of selected mobile phase which gave good separation and symmetrical peak shape was toluene: ethyl acetate: formic acid (15: 10.5: $1.5 \mathrm{v} / \mathrm{v} / \mathrm{v}$ ) with a wavelength of $279 \mathrm{~nm}$, time of saturation was 60 minutes, elution distance was $8 \mathrm{~cm}$ and volume of spots was $10 \mu \mathrm{L}$. Stability tests showed a decrease in area and shift of Rf during storage. Conclusion: In this study, the optimal condition for analysis of phyllanthin in the P. niruri extracts has been proposed and successfully applied for stability test in the pre-validation stage of the method develepoment. Phyllanthin was unstable during storage, therefore standard solutions and extracts should be made fresh to maintain the stability.
\end{abstract}

Keywords: phyllanthin, optimization of analytical methods, stability, TLC-densitometry

\begin{abstract}
Abstrak
Pendahuluan: Filantin merupakan senyawa lignan utama pada Phyllanthus niruri yang menunjukkan aktivitas hepatoprotektif. Untuk keperluan standardisasi ekstrak, metode kromatografi lapis tipis (KLT)-densitometri yang sederhana dan selektif telah dikembangkan dalam penelitian ini dengan menggunakan filantin sebagai marker fitokimia. Tujuan: Untuk menetapkan kondisi analisis KLT-densitometri yang optimal dan mengevaluasi stabilitas filantin. Metode: Penentuan kondisi optimal analisis dilakukan dengan cara menentukan komposisi fase gerak, panjang gelombang analisis, waktu penjenuhan bejana, jarak elusi dan volume penotolan. Uji stabilitas filantin dilakukan dengan menganalisis larutan standar dan ekstrak pada 0, 4, 8 dan 24 jam. Hasil: Komposisi fase gerak terpilih yang menghasilkan pemisahan yang baik dan bentuk puncak yang simetris yaitu toluen : etil asetat : asam format (15:10,5:1,5 v/v/v) dengan panjang gelombang $279 \mathrm{~nm}$, waktu penjenuhan bejana 60 menit, jarak elusi $8 \mathrm{~cm}$ dan volume penotolan $10 \mu \mathrm{L}$. Uji stabilitas larutan uji menunjukkan adanya penurunan area dan pergeseran Rf pada waktu penyimpanan. Kesimpulan: Pada penelitian ini telah diperoleh kondisi optimal untuk analisis filantin. Kondisi optimal yang diperoleh pada penelitian ini dapat digunakan untuk uji stabilitas tahap pre-validasi metode. Filantin tidak stabil selama penyimpanan, sehingga larutan baku dan ekstrak sebaiknya dibuat baru ketika akan dilakukan analisis untuk menjamin stabilitas.
\end{abstract}

Kata kunci: filantin, optimasi metode analisis, stabilitas, KLT-densitometri 


\section{PENDAHULUAN}

Bahan alam telah banyak dimanfaatkan sebagai obat karena mengandung senyawa bioaktif yang memberikan efek terapi untuk tubuh. Sebanyak 30 $40 \%$ produk obat yang beredar saat ini berasal dari bahan alam baik melalui proses isolasi maupun semi sintesis. Salah satu bahan alam yang sedang dan banyak dikembangkan untuk produk obat saat ini adalah Phyllanthus niruri. Ekstrak daun, batang dan akar tanaman ini telah lama digunakan sebagai obat di berbagai negara untuk terapi penyakit ginjal dan kandung kemih, infeksi saluran cerna, diabetes dan virus hepatitis B (Khatoon dkk., 2006).

Penelitian yang banyak dilakukan pada $P$. niruri adalah membuktikan efek hepatoprotektif (Bhattacharjee \& Sil, 2007; Krithika dkk., 2009; Chirdchupunseree \& Pramyothin, 2010). Efek hepatoprotektif pada $P$. niruri disebabkan oleh adanya senyawa filantin. Ravikumar dkk. (2011) membuktikan bahwa filantin secara bermakna menghambat enzim NS3 protease dan NS5B RNA serta mencegah replikasi virus hepatitis C. Krithika dkk. (2015) juga membuktikan bahwa filantin dapat menyebabkan hambatan pada reseptor kinase transforming growth factor (TGF) beta tipe 1 dan hambatan pada jalur pensinyalan TGF melalui ALK5, Smad 2 dan 3 sehingga mencegah fibrosis hati. Struktur filantin dapat dilihat pada Gambar 1.

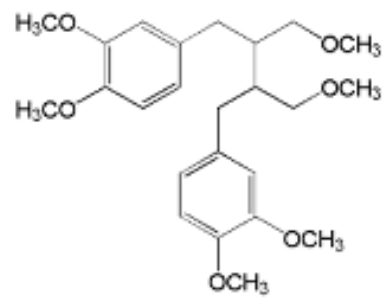

Gambar 1. Struktur filantin $\left(3,3^{\prime}, 4,4^{\prime}, 9,9^{\prime}-H e x-\right.$ methoylignan)

Di Indonesia, standar simplisia dan ekstrak yang digunakan dalam pengobatan diatur dalam Farmakope Herbal Indonesia (FHI) (Depkes RI, 2009). Pada monografi FHI, prosedur analisis herba meniran ditentukan menggunakan metode Kromatografi Lapis Tipis (KLT) dengan larutan pembanding kuersetin dan belum disebutkan metode baku untuk analisis filantin. Beberapa metode analisis untuk penentuan filantin telah dikembangkan dan metode Kromatografi Lapis Tipis Kinerja Tinggi (KLTKT) menjadi metode yang paling banyak digunakan (Tatiya dkk., 2011; Tripathi dkk., 2006; Arsul dkk., 2011; Nayak dkk., 2010;
Murugaiyah \& Chan, 2007; Khabiya dkk., 2014). Akan tetapi metode ini tidak banyak diaplikasikan oleh industri farmasi di Indonesia karena relatif lebih mahal dibandingkan metode KLT.

Penetapan kadar filantin menggunakan metode KLT pada ekstrak etanol herba meniran juga telah dilaporkan oleh Alegantina dkk (2015) menggunakan fase gerak kloroform : metanol $(9: 1)$, akan tetapi resolusi puncak filantin dalam ekstrak rendah sehingga senyawa filantin belum memisah dengan sempurna. Selain itu stabilitas filantin juga belum dilaporkan. Tujuan dari penelitian ini untuk mendapatkan kondisi optimal analisis menggunakan metode KLTdensitometri yang diharapkan memberikan hasil pemisahan yang baik dan mengevaluasi stabilitas filantin sebagai tahap awal pengembangan metode untuk analisis filantin.

\section{BAHAN DAN METODE Bahan}

Standar filantin (Sigma Aldrich), ekstrak etanol Phyllanthus niruri (Natura Lab), toluen (Merck), asam format (Merck), etila setat (Merck), metanol (Merck), n-heksana (Merck), aseton (Merck), kloroform (Merck), asetonitril (Merck).

Alat

Lempeng KLT silica gel $60 \mathrm{~F}_{254}$ aluminium sheets $20 \times 20 \mathrm{~cm}$ (Merck), bejana pengembang $10 \times 10 \mathrm{~cm}$ (Camag), KLT scanner 3 dengan UV detektor (Camag), winCATS software versi 1.4.8.2012 (Camag).

\section{Metode}

\section{Pembuatan larutan baku induk standar filantin}

Ditimbang $1,0 \mathrm{mg}$ standar filantin, dilarutkan dalam $10 \mathrm{~mL}$ metanol. Baku induk ini selanjutnya dapat digunakan untuk membuat baku kerja 20 $100 \mathrm{ppm}$ melalui tahap pengenceran.

\section{Pembuatan larutan ekstrak}

Ditimbang 1,0 gram ekstrak etanol $P$. niruri dan dilarutkan dalam $10 \mathrm{~mL}$ metanol. Larutan dipanaskan pada suhu $60^{\circ} \mathrm{C}$ diatas hotplate dan diaduk menggunakan magnetic stirrer selama 60 menit. Larutan disentrifugasi selama 2 menit dengan kecepatan 4000 rpm untuk memisahkan supernatan dan endapannya.

\section{Pembuatan fase gerak}

Untuk tahap optimasi kondisi maka fase gerak dibuat dalam beberapa macam komposisi fase gerak seperti tertera pada Tabel 1. 
Tabel 1. Variasi komposisi fase gerak yang diuji untuk mendapatkan kondisi optimal

\begin{tabular}{lll}
\hline No & Komposisi fase gerak & Perbandingan volume \\
\hline 1 & n-heksana $:$ aseton : etil asetat & $37: 6: 6 \mathrm{v} / \mathrm{v} / \mathrm{v}$ \\
2. & Kloroform : etil asetat & $1: 1 \mathrm{v} / \mathrm{v}$ \\
3. & Kloroform : asetonitril : metanol : asam format & $60: 30: 10: 0,5 \mathrm{v} / \mathrm{v} / \mathrm{v} / \mathrm{v}$ \\
4. & Toluen : etil asetat $:$ asam format & $15: 10,5: 1,5 \mathrm{v} / \mathrm{v} / \mathrm{v}$ \\
\hline
\end{tabular}

\section{Optimasi kondisi analisis}

Optimasi kondisi analisis dilakukan dengan cara mengubah komposisi fase gerak, menentukan panjang gelombang maksimum untuk pengamatan noda, optimasi waktu penjenuhan bejana selama 15 - 90 menit, optimasi jarak elusi pada panjang $7-9 \mathrm{~cm}$ dan optimasi volume penotolan sebanyak $6-20 \mu \mathrm{L}$ pada plat KLT. Parameter yang diamati dalam pemilihan kondisi optimal adalah faktor retardasi (Rf), bentuk puncak dan resolusi (Rs) terbaik. Rs dihitung menggunakan rumus matematika sebagai berikut:

$$
R=\frac{2(\max R f 1-\max R f 2}{(\text { end } R f 1-\text { start } R f 1)+(\text { end } R f 2-\operatorname{start} R f 2)}
$$

Keterangan:

Rs $\quad=$ resolusi

Rf1 = faktor retardasi senyawa 1

Rf2 = faktor retardasi senyawa 2

\section{Uji stabilitas larutan uji}

Uji stabilitas dilakukan dengan membagi larutan standar dan ekstrak dalam 4 tabung berbeda. Masingmasing tabung diberi label 0 jam, 4 jam, 8 jam, dan 24 jam. Larutan uji dianalisis sesuai waktu yang telah ditentukan dalam label. Semua tabung disimpan pada suhu $4^{\circ} \mathrm{C}$.

\section{HASIL DAN PEMBAHASAN}

\section{Optimasi kondisi analisis}

Berdasarkan percobaan yang telah dilakukan terhadap variasi komposisi fase gerak, diperoleh data pada Tabel 2. Komposisi fase gerak 1 menunjukkan resolusi yang baik antara puncak filantin dan pengotornya yaitu > 1,5 akan tetapi puncak filantin fronting. Hal ini dapat mempengaruhi hasil analisis sehingga fase gerak 1 tidak dipilih. Komposisi fase gerak 2 menunjukkan resolusi $<1,5$ sehinga puncak filantin tidak terpisah sempurna dengan puncak pengotornya. Selain itu puncak filantin juga fronting sehingga fase gerak 2 tidak dipilih. Komposisi fase gerak 3 tidak menunjukkan adanya puncak filantin yang terelusi, sehingga fase gerak 3 tidak dipilih.Komposisi fase gerak 4 menunjukkan resolusi yang paling optimal dan puncak yang simetris, sehingga fase gerak ini dipilih dan digunakan untuk proses analisis selanjutnya.
Tabel 2. Data hasil percobaan variasi komposisi fase gerak

\begin{tabular}{ccccc}
\hline $\begin{array}{c}\text { Fase } \\
\text { gerak }\end{array}$ & Rf & Rs1 & Rs2 & Puncak \\
\hline 1 & 0,37 & 1,7 & 2,1 & Fronting \\
2 & 0,78 & 1,1 & - & Fronting \\
3 & NA & NA & NA & NA \\
4 & 0,66 & 7,3 & 1,8 & Simetris \\
\hline
\end{tabular}

*NA: puncak tidak terdeteksi.

Panjang gelombang maksimal yang terdeteksi yaitu $200 \mathrm{~nm}$. Akan tetapi apabila dilakukan analisis pada panjang gelombang tersebut maka banyak puncak pengganggu yang muncul dan dapat mempengaruhi hasil analisis senyawa filantin. Pada panjang gelombang $279 \mathrm{~nm}$, area yang dihasilkan puncak filantin tinggi dan puncak pengganggu yang dihasilkan sangat sedikit sehingga panjang gelombang terpilih yang digunakan yaitu $279 \mathrm{~nm}$ (Gambar 2).

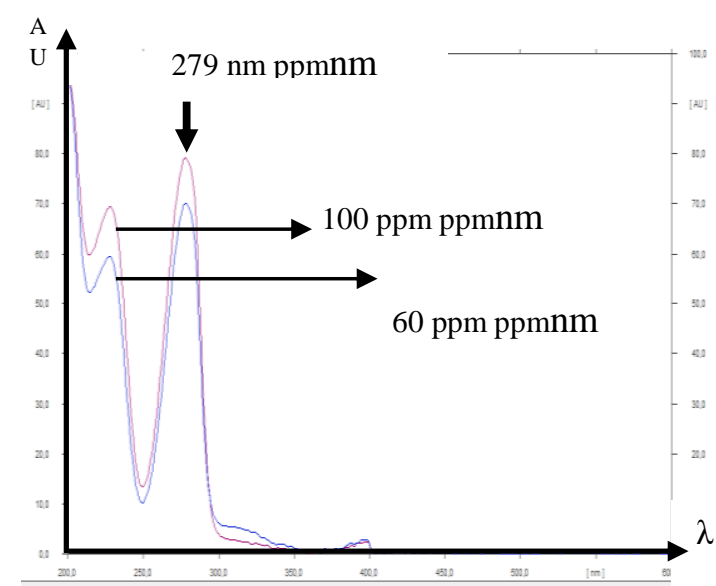

Gambar 2. Spektra dan panjang gelombang senyawa filantin

Penjenuhan bejana dengan sempurna diperlukan agar proses elusi dan pemisahan dapat berjalan dengan baik. Hasil optimasi waktu penjenuhan bejana tertera pada Tabel 3. Dari hasil optimasi diperoleh waktu penjenuhan bejana dapat mempengaruhi Rf. Hal ini sesuai dengan penelitian yang dilakukan oleh Dezeeuw (1968) yang menunjukkan ketidakstabilan Rf suatu senyawa setelah dielusi pada bejana yang tidak dilakukan penjenuhan.Waktu penjenuhan bejana yang optimal pada penelitian ini yaitu minimal 60 menit karena Rf stabil setelah 60 menit. 
Tabel 3. Data hasil optimasi waktu penjenuhan bejana

\begin{tabular}{ccc}
\hline $\begin{array}{c}\text { Waktu penjenuhan } \\
\text { (menit) }\end{array}$ & Area & Rf \\
\hline 15 & 921,4 & 0,59 \\
30 & 956,6 & 0,61 \\
60 & 1098,8 & 0,66 \\
90 & 1095,0 & 0,66 \\
120 & 1084,8 & 0,66 \\
\hline
\end{tabular}

Hasil optimasi volume penotolan tertera pada Tabel 4. Berdasarkan hasil yang diperoleh, volume penotolan yang memberikan bentuk puncak simetris yaitu $6 \mu \mathrm{L}$ dan $10 \mu \mathrm{L}$. Pada volume penotolan $16 \mu \mathrm{L}$ dan $20 \mu \mathrm{L}$, puncak mengalami fronting. Hal ini dapat disebabkan volume penotolan terlalu besar. Berdasarkan penelitian yang telah dilakukan oleh Tripathi dkk. (2006), Khabiya dkk. (2014) dan Alegantina dkk. (2015), diperoleh kadar filantin yang relatif kecil sehingga volume penotolan $10 \mu \mathrm{L}$ lebih dipilih pada penelitian ini dibandingkan $6 \mu \mathrm{L}$.

Tabel 4. Data hasil optimasi volume penotolan

\begin{tabular}{cccl}
\hline $\begin{array}{c}\text { Konsentrasi } \\
(\mathrm{ng} / \mu \mathrm{L})\end{array}$ & $\begin{array}{c}\text { Volume } \\
\text { totolan } \\
(\mu \mathrm{L})\end{array}$ & Area & Puncak \\
\hline 20,14 & 6 & 531,4 & Simetris \\
20,14 & 10 & 1069,8 & Simetris \\
20,14 & 16 & 1688,1 & Fronting \\
20,14 & 20 & 2125,0 & Fronting \\
\hline
\end{tabular}

Jarak elusi juga telah dioptimasi pada penelitian ini. Hasil optimasi tertera pada Tabel 5. Hasil yang diperoleh menunjukkan bahwa jarak elusi dapat mempengaruhi Rf dan Rs. Pemisahan yang paling baik didapatkan pada jarak elusi $9 \mathrm{~cm}$. Akan tetapi jarak elusi $8 \mathrm{~cm}$ juga memenuhi persyaratan Rs yaitu > 1,5.
Untuk menghemat waktu elusi maka dipilih jarak elusi $8 \mathrm{~cm}$.

Tabel 5. Data hasil optimasi jarak elusi

\begin{tabular}{cccc}
\hline $\begin{array}{c}\text { Jarak elusi } \\
(\mathrm{cm})\end{array}$ & Rf & Rs1 & Rs2 \\
\hline 7 & 0,54 & 6,1 & 1,2 \\
8 & 0,66 & 7,3 & 1,8 \\
9 & 0,72 & 7,5 & 2 \\
\hline
\end{tabular}

\section{Stabilitas larutan uji}

Uji stabilitas pada larutan standar dan ekstrak merupakan salah satu uji yang dilakukan pada tahap pre-validasi. Uji stabilitas ini dilakukan untuk mengevaluasi stabilitas larutan uji pada waktu penyimpanan tertentu. Analit pada larutan uji dikatakan stabil apabila selisih area maupun faktor retardasi sebesar $2 \%$ terhadap analit pada larutan uji yang baru dibuat dan langsung dianalisis (Indrayanto, 2012). Hasil uji stabilitas larutan uji pada beberapa waktu pengukuran dapat dilihat pada Tabel 6 dan Tabel 7.

Berdasarkan data yang diperoleh diketahui bahwa larutan uji tidak stabil setelah penyimpanan 4 jam. Kemudian dilakukan analisis menggunakan SPSS untuk menentukan apakah terdapat perbedaan bermakna antara area dan faktor retardasi pada setiap waktu pengamatan. Data yang diperoleh menunjukkan distribusi normal dan homogen sehingga dilakukan pengujian dengan one-way ANOVA. Hasil analisis menunjukkan terdapat perbedaan bermakna rata-rata area dan Rf pada setiap waktu pengamatan. Hal tersebut menunjukkan bahwa semakin lama larutan standar disimpan maka akan semakin menurun kadarnya (Gambar 3).

Tabel 6. Hasil uji stabilitas larutan standar dalam waktu tertentu

\begin{tabular}{ccccc}
\hline Waktu pengamatan (jam) & Rata-rata Area & Selisih area (\%) & Rf & Selisih Rf $(\%)$ \\
\hline 0 & $7421,0 \pm 0,5$ & - & 0,66 & - \\
4 & $6829,7 \pm 0,4$ & 7,9 & 0,67 & 1,5 \\
8 & $6715,3 \pm 0,5$ & 9,5 & 0,71 & 7,5 \\
24 & $6579,4 \pm 0,5$ & 11,3 & 0,71 & 7,5 \\
\hline
\end{tabular}

Tabel 7. Hasil uji stabilitas larutan ekstrak dalam waktu tertentu

\begin{tabular}{ccccc}
\hline Waktu pengamatan (jam) & Rata-rata Area & Selisih area (\%) & Rf & Selisih Rf $(\%)$ \\
\hline 0 & $2889,7 \pm 0,3$ & - & 0,62 & - \\
4 & $2883,9 \pm 0,5$ & 0,2 & 0,58 & 6,4 \\
8 & $2671,9 \pm 0,3$ & 7,5 & 0,58 & 6,4 \\
24 & $2452,2 \pm 0,3$ & 15,1 & 0,56 & 9,7 \\
\hline
\end{tabular}




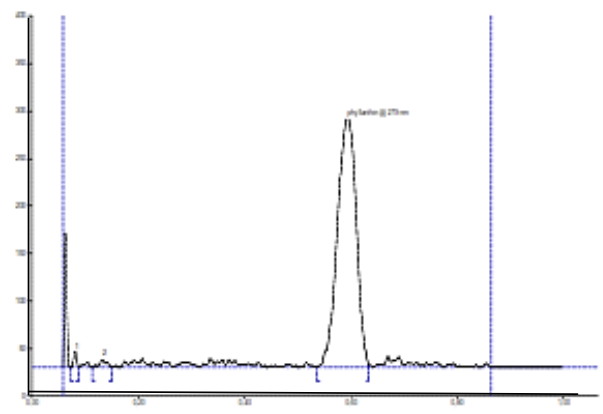

(a)

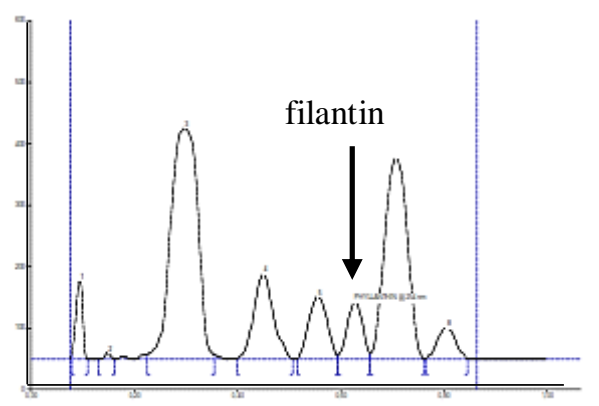

(b)

Gambar 3. Kromatogram standar filantin (a) dan ekstrak filantin (b) menggunakan fase gerak toluen : etil asetat : asam format (15:10,5:1,5 v/v/v)

\section{KESIMPULAN}

Kondisi optimal yang diperoleh pada penelitian ini untuk analisis filantin adalah komposisi fase gerak toluen : etil asetat : asam format (15:10,5 : 1,5 v/v/v) dengan lama penjenuhan 60 menit, panjang gelombang analisis $279 \mathrm{~nm}$, jumlah penotolan $10 \mu \mathrm{L}$ dan jarak elusi $8 \mathrm{~cm}$. Stabilitas larutan diuji pada penelitian ini sebagai tahap prevalidasi. Stabilitas larutan uji menurun dengan penyimpanan pada waktu tertentu ditandai dengan penurunan area dan pergeseran faktor retardasi pada kromatogram filantin. Disarankan untuk larutan uji dibuat baru ketika akan dilakukan analisis. Pada penelitian selanjutnya dapat dilakukan validasi metode untuk kondisi optimal yang telah diperoleh.

\section{DAFTAR PUSTAKA}

Alegantina, S., Setyorini, H. A. \& Triwahyuni. (2015). Pengujian Mutu dan Penetapan Kadar Filantin Pada Ekstrak Etanol Herna Meniran (Phyllanthus niruri Linn). Buletin Penelitian Kesehatan; 43; 11-16.

Arsul, V. A., Ganjiwale, R. \& Yeole, D. (2011). Development and Validation of Phyllanthin by HPTLC in Hepatoprotective Polyherbal Tablet Dosage Form. Asian Journal of Research in Chemistry; 4; 815-817.

Bhattacharjee, R. \& Sil, P. (2007). Protein Isolates from the Herb, Phyllanthus niruri L. (Euphorbiaceae), Plays Hepatoprotective Role
Against Carbon Tetrachloride Induced Liver Damage Via Its Antioxidant Properties. Food and Chemical Toxicology; 45; 817-826.

Chirdchupunseree, H. \& Pramyothin, P. (2010). Protective Activity of Phyllanthin in EthanolTreated Primary Culture of Rat Hepatocytes. Journal Ethnopharmacol; 128; 172-176.

Departemen Kesehatan Republik Indonesia (Depkes RI). (2009). Farmakope Herbal Indonesia. Jakarta: Departemen Kesehatan Republik Indonesia

Dezeeuw, R. A. (1968). Reproducibility of Rf Values in Unsaturated Chambers and Related Development Techniques. Journal of chromatography; 33; 222-226.

Indrayanto, G. (2012). Validation of Analytical Methods. Profiles of Drug Subtances, Excipients, And Related Methodology; 37; 439-463.

Khabiya, R., Upadhyay, D., Srivastava, A. \& Anandjiwala, S. (2014). Simultaneous Quantification of Three Bioactive Lignans, Viz., Phyllanthin, Hypophyllanthin and Niranthin from Phyllanthus amarus Using High-Performance Thin-Layer Chromatography. Journal of planar chromatography; 27; 281-286.

Khatoon, S., Rai, V., Rawat, A. \& Mehrotra, S. (2006). Comparative Pharmacognostic Studies of Three Phyllanthus Species. Journal of Ethnopharmacology; 104; 79-86.

Krithika, R., Jyothilakshmi, V., Prashantha, K. \& Verma, R. J. (2015). Mechanism of Protective Effect of Phyllanthin Against Carbon Tetrachloride-Induced Hepatotoxicity and Experimental Liver Fibrosis in Mice. London: Taylor \& Francis.

Krithika, R., Mohankumar, R., Ramtej, J. Y. \& Shrivastav, P. S. (2009). Isolation, Characterization and Antioxidative Effect of Phyllanthin Against CCL-induced Toxicity in HepG2 Cell Line. Chemico-Biological Interactions; 181; 351-358.

Murugaiyah, V. \& Chan, K.. L. (2007). Determination of Four Lignans in Phyllanthus niruri L. by a Simple High-Performance Liquid Chromatography Method with Fluorescence Detection. Journal of Chromatograpphy A; 1154; 198-204.

Nayak, P. S., Upadhyay, A., Dwivedi, S. K. \& Rao, S. (2010). Quantitative Determination of Phyllanthin in Phyllanthus amarus by High Performance Thin Layer Chromatography. Boletin Latinoamericano 
y del Caribe de Plantas Medicinales y Aromaticas; 9; 353-358.

Ravikumara, Y., Raya, U. \& Nandhithaa, M. (2011). Inhibition of Hepatitic $\mathrm{C}$ Virus Replication by Herbal Extract: Phyllanthus amarus as Potent Natural Source. Virus Research; 158; 89-97.

Tatiya, A., Patil, R., Sutar, M., Shirkhedkar, A. \& Surana, S. (2011). Determination of Phyllanthin and Galic Acid in Herbal Hepatoprotective
Formulation by TLC-Densitometry Analysis. Pharmacognosy Journal; 3; 39-43.

Tripathi, A. K., Verma, R. K., Gupta, A. K., Gupta, M. M. \& Khanuja, S. P. (2006). Quantitative Determination of Phyllantine and Hypophyllantine in Phyllantus Species by HighPerformance Thin Layer Chromatography. Phytochemical Analysis; 17; 394-397. 